\title{
Leaving the Twentieth Century Behind
}

A Conversation between Gao Xingjian and Liu Zaifu

\section{CpenEdition}

\section{Journals}

Electronic version

URL: http://journals.openedition.org/chinaperspectives/4143

DOI: $10.4000 /$ chinaperspectives. 4143

ISSN: 1996-4617

\section{Publisher}

Centre d'étude français sur la Chine contemporaine

Printed version

Date of publication: 1 July 2008

Number of pages: 118-122

ISSN: 2070-3449

\section{Electronic reference}

"Leaving the Twentieth Century Behind », China Perspectives [Online], 2008/3 | 2008, Online since 01 July 2011, connection on 28 October 2019. URL : http://journals.openedition.org/chinaperspectives/ 4143 ; DOI : 10.4000/chinaperspectives. 4143

(C) All rights reserved 


\title{
Leaving the Twentieth
}

\section{Century Behind}

\author{
A Conversation between Gao Xingjian and Liu Zaifu
}

Gao Xingjian, laureate of the 2000 Nobel Prize for literature, visited Hong Kong at the invitation of the French Centre for Research on Contemporary China (CEFC) and the Chinese University of Hong Kong (CUHK) in May 2008. He took part in a series of events: an international academic conference co-organised by the CEFC and CUHK in collaboration with the University of Provence, the inauguration of an exhibition of his ink paintings, the world premiere of his play Of Mountains and Seas, and the launch of his new collection of essays, On Creation (Lun chuangzuo, Taipei, Lianjing, 2008). On this occasion, Mingpao Monthly organised a discussion between Gao Xingjian and Liu Zaifu, a prominent Chinese intellectual who has lived in the United States since 1989, and who is author of the much-debated essay Farewell to Revolution (with Li Zehou, 1995) and of the preface to Gao's new volume. The debate was moderated by professor Park Jae-woo (Hankuk University of Foreign Studies, Seoul). (SV)

Liu Zaifu: It saddens me to think that at the time of the May Fourth New Culture movement Kafka was unknown to modern Chinese writers; yet he has become the point of departure for Gao Xingjian's works, from Bus stop (Chezhan) to Week-end quartet (Zhoumo si chong zou) and Nocturnal wanderer (Yeyou shen), all of which are an intensification of Kafka. Gao has shifted from Kafka's concern with the external world to a concern with the interior self, and has entered a deep spiritual abyss. When Gao speaks of "getting out of the twentieth century," the key to this idea is that humanity should move away from its familiar twentieth-century ways of being and ways of thinking and should reflect on, question, and even reject the roles it played and the goals it pursued in the twentieth century. We are very conscious of the fact that we do not have the power to transform the world and remould human nature; all we can do is strive to break away from some of the "commonly accepted views" and habitual ways of thinking of our own profession, by which I mean literature and art; the misapprehension, for instance, that writers can save the world, or that they can act as the conscience of society and are the embodiment of justice. I particularly want to make it clear that among contemporary writers, Gao Xingjian is that rare thing, a discoverer, interpreter, and publicist of the individual nature of writers and of literature.

On the one hand, Gao affirms the standpoint of the individuality of the writer as independent subject, and on the other he acknowledges, much more than many contemporary writers do, the individual features of literature and writing in themselves, and strives to defend the nature of literature and art. In the twentieth century, literature was defined variously as "a mirror of the age," "a political barometer," "ideology expressed in images," "cultural consumption for the masses," "a market commodity," "the dagger and spear of struggle," "a tool of social and cultural criticism," and so on. To Gao, all of these definitions run counter to, or even profane, the very nature of literature. In his On creation he is constantly reminding himself that he must not fall into the quagmire of orientation.

Commitment is not the essence of literature after all, it represents a form of otherness for literature. The direction a writer's soul takes is a natural one, whereas commitment is an artificial utilitarian tendency. A political orientation is always something imposed on the reader's a priori ideology. It does not evoke the reader's own personal experiences and psychological resonances, and that is why it will inevitably damage the truth and beauty of literature itself. In "A different kind of aesthetics" (Ling yizhong meixue), "The place of the writer" (Zuojia de weizhi), and "The aesthetics of the artist" (Yishujia meixue), Gao repeatedly aims his criticism at postmodernism, maintaining that it is a symptom of the age. $\mathrm{He}$ is well aware that an -ism such as this is far removed from the essence of literature as art. What is known as "subversiveness" is an extreme form of commitment that knows only deconstruction and destruction and lacks any idea of construction or achievement. Its process of continual revolution and continual subversion increasingly distances it from the true nature of literature and art. The great upheavals experienced in twentieth-century art were closely linked to such thinking. One important element in "Leaving the twentieth century behind" is the move away from the sickness of postmodernism and its ideological tendency towards revolution in art. The theme of our discussion today is thus a return to literature, to the role of the writer as simply an observer, a wit- 



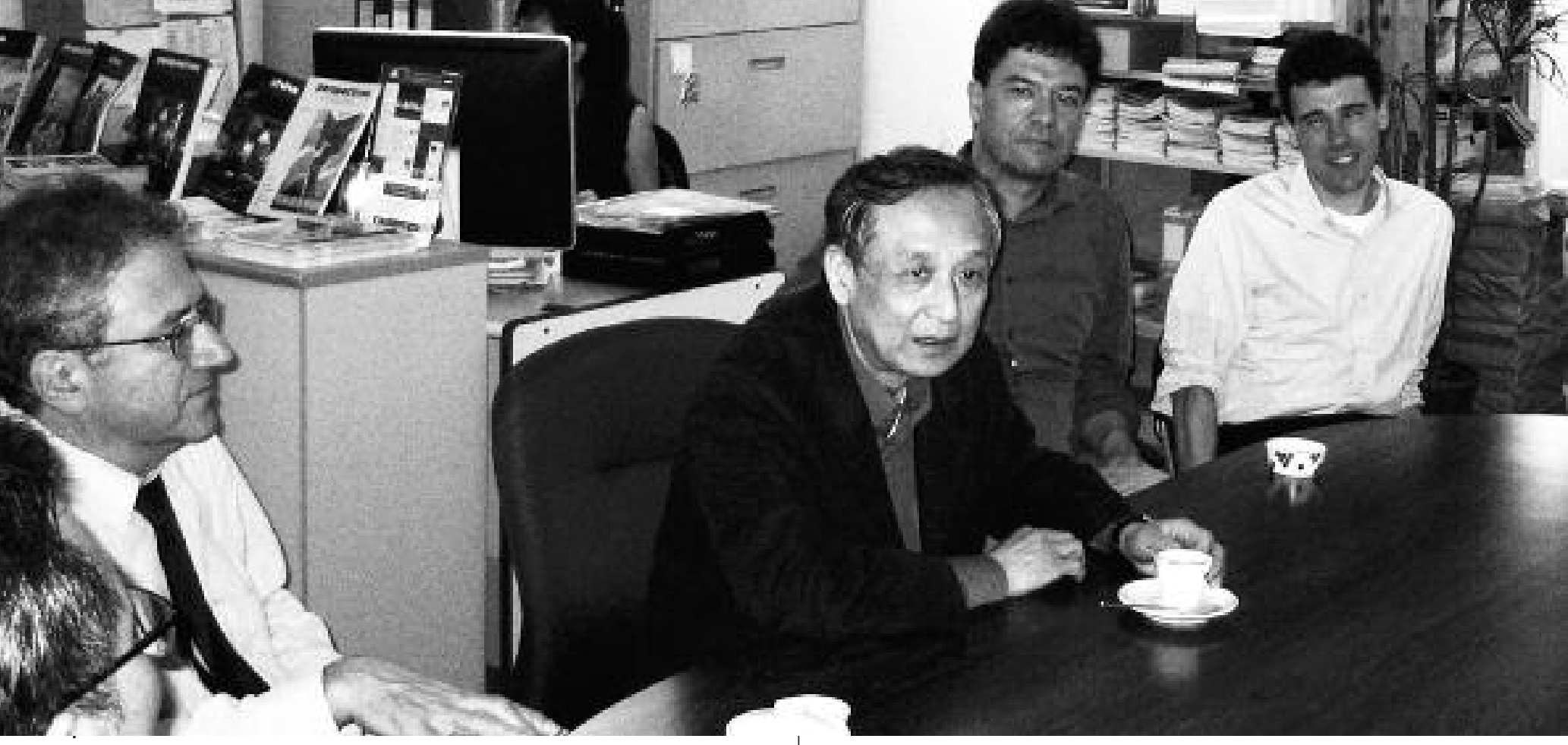

Gao Xingjian visiting the CEFC, surrounded by Prof. Noël Dutrait, Jean-François Huchet and Sebastian Veg. () CEFC

a common perception that it is not possible, and the fact that we encounter this perception everywhere simply goes to show how this kind of ideology and this kind of politics have already got a hold on this age of ours, and how far they have penetrated into people's minds.

Literature was originally something that shaped a person's disposition - what connection does it have with politics? Literature is a way of perceiving people and society, and this perception is different for each of us. Everyone knows that a good work of literature is of value forever; from the Greek tragedies to Shakespeare to Cao Xuegin, such a work transcends the age in which it was written, and of course also transcends the politics of the time, ethical and moral norms, and linguistic and national boundaries. Why? Because it portrays the fundamentals of mankind's existence, the basic conditions for mankind's existence, and in so doing it gives rise to all manner of enigmas. Basic human nature, in all its complexity and bewilderment, is what literature and art are all about. Without people, without human feelings, literature becomes merely a vehicle for concepts, an intellectual game, a business operation, or a political tool, and to my mind literature and art of this sort are pathetic and actually have no freedom at all. How can artists or writers resist this tide, which is spreading over the earth? I don't think they can. If you choose to fight it, I can only express my sincerest respect for you. I truly admire the courage of such people I admire them because they are doomed, like Sisyphus, to stay in the terrible prison of achieving nothing.

If a writer, a single weak individual, a thoroughly flawed person, wants to use his limited life to fight against the unlimited mechanism that is society, he is destined to lose, and the role he plays cannot but be a tragic one. That is where the myth of Sisyphus is so profound. Actually, man has been faced with this dilemma ever since he came into existence. I hope that in future our thinking will be able to escape from the framework of ideology, to get away from the disasters that haunted the twentieth century, including the dark shadows that pervade Marxism, and discover a new, fresh mentality with which we can confront the difficulties facing us today. We do not know whether such a new mentality will be able to provide a solution, but as things are at present we have no way of proposing any solution at all. All I can do is raise the issue, if I still want to be able to think independently and attain a form of inner freedom.

Liu: There is a radical dimension to Gao Xingjian's thinking; what he is exploring is not the usual link between literature and politics. He is adamant that literature absolutely cannot be permitted to get involved in politics or ideology; if it does, it will destroy itself. His point of view is unequivocal and I have found it hugely stimulating. He has formulated it on many levels. I remember, when I met him in Paris, he told me that from now on we must raise aloft the banner of escape and refuse to get involved in politics. Our escape is not a political rebellion, but a persistent effort to save ourselves, or perhaps an aesthetic escape, a literary escape. We must win time, access our spiritual values in order to create, return to our own individual standpoints, and speak out with our own personal voices. This was a great and thoroughgoing inspiration to me. Since then he has used his ideas and theories to formulate these thoughts from many different angles. For China's contemporary writers, this is a very special point: Gao has laid down a marker. 
But there is something I have been wondering about - after Gao won the Nobel prize in 2000, Professor Park Jae-woo of Korea wished to hold a major symposium in Korea entitled "From Lu Xun to Gao Xingjian," an excellent choice of theme. Although this was never followed up, due to problems obtaining permits, it made me think. Of the two main types of modern Chinese literature, one is hot and the other is cold. Lu Xun is seen as the model, the classic example, of hot literature, Gao Xingjian as the representative of cold literature. How ought we to regard these two major types?

$\mathrm{Lu}$ Xun is my idol, and I believe that even now none of China's modern writers can surpass him. The last line of his "Diary of a Madman" is "Save the children...": such was Lu Xun's ambition to save the world. Gao Xingjian's writing, on the other hand, is entirely his own - he has no ambition to save the world, he wants to save himself, and that is completely different. Lu Xun showed time and time again that he embraced society warmly and cared passionately about justice. That is why he was so angry when writers attacked one another, and why he wrote a series of seven essays to the effect that they, too, should embrace society. That is also why he so detested Zhuangzi. Gao Xingjian thinks differently, however. He does not refuse to embrace society, but he distances himself from ideas of right and wrong and views them coldly, and so he takes a dispassionate view of society.

Thus while Lu Xun's favourite writer was Xi Kang, ${ }^{(1)} \mathrm{Gao}$ 's favourite writer is Huineng. ${ }^{(2)}$ We know that Huineng refused to have anything to do with politics. Gao's play Snow in August is actually the tale of his own soul, and the character of Huineng is Gao himself, so what Huineng advocates in the play is the truth of the total wisdom and total detachment of the individual. But how can total freedom and total detachment be obtained? The most important thing is not to become involved with politics. So, when Wu Zetian invites Huineng to the palace and wants to give him a title, put up a monument to him and build him a temple, Huineng refuses. Wu Zetian despatches a general to invite him, and Huineng says, "You can cut off my head and take it away, but I still cannot go." The reason is that he knows that as soon as he sets foot in the palace he will be nothing but an ornament and will lose his freedom and his detachment. Gao has formulated this very thoroughly. And this is where there is a problem, because Gao believes he should take up just such a role, and distance himself completely from society. When I was lecturing on Gao in Singapore, I described him as Zen inside and out, in fact Zen all the way through, and that description fits Huineng, too. I am not the same as him, in that I am outwardly Confucian and inwardly Zen. Outwardly I have social concerns, but inside I am Zen. So I now have some questions for Xingjian: what is your view of social concerns? And what is your view of writers such as Lu Xun?

Gao: At the present time, there are many writers like him, and some of them are extremely good. Kenzaburō $\overline{\mathrm{O}} \mathrm{e}^{(3)}$ is one whom I know and appreciate enormously. I tell him, "The tragic hero - that's you," and we understand each other very well. I believe he has a lot of experience of this, of something that is extremely difficult to do. I can only admire him from the bottom of my heart, for wanting, as a lone individual, to challenge society, to point up so many social obligations. He's like a warrior fighting on with his head under his arm, and from afar I wish him well as he continues his battle. I do not dismiss the choice he made - he is that sort of writer, who still exists today, and he throws himself into reallife politics because he has his own opinions, his own political views. In addition to his literary creation, he has a social role to play. But I think that the artist or writer should also be allowed to have a different choice, so I am also proposing "without-ism." This is not to say that I am proposing an -ism that lacks an ideology, or that mine is the only right way, the only one permitted, the only correct one. I go so far as to propose a judgement in which there is no right or wrong, since right and wrong are both relative. We no longer have ethical judgements these days, because ever since politics has pervaded everything, ethical judgement has been replaced by political correctness. And judgements of right and wrong are hard to make, since what is right today was wrong yesterday. If people say that writers should engage in politics, and should be legislators or ministers, I feel there is nothing to be said against it. I'm not saying that politics is an occupation that is damned, and I know that someone who wants to be a politician can accomplish great things. But I consider that politicians have no freedom, no personal freedom. In line with all political establishments, where the balance of rights and interests and the exercise of power is concerned, a politician needs to have sufficient wisdom and skill to maintain that balance, otherwise he, too, may be sacrificed. But if a writer or artist does not aspire to power and carries no political burden, does he still have a right to exist?

I have one criticism of Lu Xun in this regard, which is that he does not permit any other opinions, any other kinds of

1. The third-century Daoist philosopher and alchemist, one of the Seven Wise Men of the Bamboo Grove (TN).

2. The sixth patriarch of Zen Buddhism, in the Tang dynasty (TN).

3. 1994 winner of the Nobel Prize for Literature (TN). 
existence. For example, his contemporary Wang Guowei drowned himself - is that not a choice of sorts? Wang wanted to escape the chaos of the time, to liberate his own thoughts. Wang's knowledge of Dream of the Red Chamber was profound, and his work on it is still regarded as having great depth today. Should a Wang Guowei be allowed to survive at a time of national chaos, civil war, and invasion such as China suffered in the twentieth century? Social conditions at the time did not allow it, and thus Wang had no option but suicide and threw himself into the Kunming Lake. That was a tragedy. The contribution that Lu Xun made to Chinese letters will never be erased; it was a symbol of that era. But is it the only symbol of the twenty-first century today? That is my question.

I am by no means opposed to people who want to be latterday Lu Xuns and take on so much social responsibility - as long as they have that kind of courage, and the tenacity to carry on, that is admirable. But it has to be allowed that there are other ways of thinking besides immersing oneself in politics. These ways are not necessarily inferior to political thinking. Quite the opposite, in fact, for some basic ways of thinking transcend the scope of politics. Who has borne witness to the basic conditions of man's existence, for example, and the complexity of human nature? Not the politicians, nor the writings of officials or of the privileged - it is History with a capital $\mathrm{H}$ that has left behind a testimony to mankind's existence, and it is works of art created by individual writers and artists that have left behind a testimony to human nature, a testimony that transcends the ages in which they lived. The tragedies of ancient Greece or Shakespeare transcend all language barriers, all national boundaries, and they have left behind a testimony to human nature and have borne witness to the hardship of man's existence. I think we should allow writers and intellectuals to think even more deeply, and transcend realistic utilitarian thinking. As I see it, this is also a type of concern for society, but a type that bears no relation to the social utilitarianism of the present time, for literature is non-utilitarian.

Liu: Gao Xingjian has just told us that he himself chooses to think in this way, while at the same time he respects $\mathrm{Lu}$ Xun's thinking: we should respect different modes of being in literature. We should acknowledge that the fundamental lesson of the twentieth century was that we made ideology a prerequisite for creation, the framework within which creation could occur, and this became increasingly evident after Mao Dun's Midnight [ $Z_{i}$ ye]. One might say that the fundamental lesson we have learned is that we have changed, and what we have been doing is using images to express ideology. We have left the twentieth century behind now, but if we cannot leave this lesson behind us, too, we are likely to repeat some of the tragedies of that century.

Park Jae-woo: I was originally very interested in Lu Xun, and have since developed a high regard for his antithesis, Gao Xingjian. I do believe that there are still some things that Lu Xun and Gao have in common - having wracked my brains, I have decided that apparent differences are due to the fact that times have changed. In Lu Xun's time, China was in a semi-colonial situation, and thus $\mathrm{Lu}$ Xun thought in depth about national sovereignty, and also took practical action, concerning himself with such issues as being a torchbearer for China's destiny. But in Gao Xingjian's age, things have changed: living in a society of high-pressure politics he was subjected to a great deal of pressure in his writing, which ultimately caused him to go into exile abroad. That is the background to the way he thinks. In Korea, I and my colleagues see him as advocating an existence that rejects utilitarian interests, -isms and the market, maintaining distance, neutrality and variety, as someone who thinks independently and has grasped the original spirit of literature. This kind of thinking is of course utterly fresh and unique, and shows an outstanding capacity for thinking about Chinese literature. However, other colleagues in Korea see this as just another way of getting involved in Chinese politics.

A moment ago, Gao Xingijian responded that this is not the same as the old literature of social concern. If $\mathrm{Lu} \mathrm{Xun}_{\mathrm{und}}$ Gao Xingijan have anything in common, it is probably that although Lu Xun's thinking was that of a social revolutionary, in the struggles of the 1930s he did, I have discovered, espouse some liberal ideas. Gao now lives in a different environment, in which he benefits from the independence of literature and the ideal of diversity. Here he strives for liberalism, for the independence of literature, and the independence of the individual. A concern for independence of character is what the two of them have in common. Gao, too, passionately ponders questions concerning society and man, but his thinking is cold; it is a capacity for thought that is different from the past. However, basically he and $\mathrm{Lu} \mathrm{Xun}_{\mathrm{ure}}$ the same kind of Chinese, each of them full of respect for literature and for independence. That is why, on the surface, one appears hot and the other cold, but essentially they are both hot. •

- First published in Ming Pao Monthly, July 2008.

- Translated from the Chinese by Caroline Mason. 